\title{
Hydrogen peroxide mediates interleukin- $1 \beta$-induced AP-1 activation in articular chondrocytes: Implications for the regulation of iNOS expression
}

\author{
A. Ferreira Mendes ${ }^{1,2}$, M.M. Caramona ${ }^{1}$, A.P. Carvalho ${ }^{2}$ and M.C. Lopes ${ }^{1,2}$ \\ ${ }^{1}$ Faculty of Pharmacy and ${ }^{2}$ Centre for Neurosciences and Cell Biology, University of Coimbra, 3004- \\ 517 Coimbra, Portugal
}

Received 26 November 2002; accepted 21 May 2003

Keywords: AP-1, articular chondrocytes, hydrogen peroxide, IL-1, iNOS

\begin{abstract}
The pro-inflammatory cytokine interleukin-1 $\beta$ (IL-1) induces articular chondrocytes to produce reactive oxygen species (ROS), including hydrogen peroxide $\left(\mathrm{H}_{2} \mathrm{O}_{2}\right)$, which mediate some IL-1induced responses. This study aimed at elucidating the role of ROS, particularly $\mathrm{H}_{2} \mathrm{O}_{2}$, in mediating IL-1-induced activation of the transcription factor activator protein-1 (AP-1) in primary cultures of articular chondrocytes. AP-1 may function either as an inducer or as a repressor of the inducible nitric oxide synthase (iNOS) gene promoter. Since we observed that AP-1 is not required for iNOS expression in chondrocytes, we also investigated whether it is a repressor of this gene. The results of electrophoretic mobility shift assays showed that both IL-1 and $\mathrm{H}_{2} \mathrm{O}_{2}$ activated AP-1 and that inhibition of IL-1-induced ROS production abrogated AP-1 activation. The AP-1 complexes, induced by either IL-1 or $\mathrm{H}_{2} \mathrm{O}_{2}$, contained c-Fos/c-Jun and c-Fos/JunD heterodimers, but IL-1 activated AP-1 with a kinetics slower than that observed with $\mathrm{H}_{2} \mathrm{O}_{2}$. Pre-activation of AP-1, before stimulation of the cells with IL-1, did not inhibit iNOS mRNA and protein synthesis, relative to cells treated with IL-1 alone. These results indicate that $\mathrm{H}_{2} \mathrm{O}_{2}$ is a major mediator of IL-1-induced AP-1 activation in articular chondrocytes and that inhibition of ROS production is an effective strategy to block this IL-1-induced response. This study also identifies c-Fos/c-Jun and c-Fos/JunD heterodimers as the AP-1 transcription factors induced by IL-1, which, although not involved in the transcriptional regulation of the iNOS gene, may be important for the regulation of other genes also relevant in arthritic diseases, namely the collagenase-1 and IL-8 genes.
\end{abstract}

Abbreviations: AP-1, activator protein-1; DPI, diphenyleneiodonium chloride; GAPDH, glyceraldehyde-3-phosphate dehydrogenase; $\mathrm{H}_{2} \mathrm{O}_{2}$, hydrogen peroxide; IL-1, interleukin-1 $\beta$; IL-8, interleukin-8; iNOS, inducible nitric oxide synthase; MMP, matrix metalloproteinase; NF- $\kappa \mathrm{B}$, nuclear factor-kappaB; NO, nitric oxide; ROS, reactive oxygen species

\section{Introduction}

Arthritic diseases have in common clinical features of inflammation and cartilage degradation, which, at least in part, result from the augmented synthesis and release of pro-inflammatory cytokines, among which interleukin- $1 \beta$ (IL-1) has a prominent role (Pelletier et al., 1993; Weyand, 2000). IL-1 induces articular chondrocytes to produce inflammatory media- 
tors, namely prostaglandins (Knott et al., 1994) and nitric oxide (NO) (Palmer et al., 1993), and cartilage matrix degrading enzymes, such as the matrix metalloproteinases-1, -3 and -13 (MMPs-1, -3 and -13 or collagenase-1, stromelysin-1 and collagenase3, respectively) (Catterall et al., 2001; Lo et al., 1998; Mengshol et al., 2001), whereas the synthesis of cartilage matrix proteins is inhibited (Goldring et al., 1994; Taskiran et al., 1994). NO and the MMPs are thought to play major roles in the pathophysiology of arthritic diseases, contributing to the irreparable degradation of the cartilage matrix (Lotz et al., 1995). Therefore, understanding the cellular mechanisms that control the production of these mediators is of great importance for the development of new therapeutic strategies that may help revert the degradation of the cartilage matrix that occurs in arthritic diseases. Despite extensive investigation, the signal transduction pathways utilized by IL-1 to induce those responses in chondrocytes are still poorly understood.

Increasing evidence indicates that reactive oxygen species (ROS) are important mediators of IL-1-induced cellular responses (Eberhardt et al., 2002; Kuo et al., 1997). In chondrocytes, IL-1 has been shown to induce the production of various types of ROS, including hydrogen peroxide $\left(\mathrm{H}_{2} \mathrm{O}_{2}\right)$ (Rathakrishnan et al., 1992; Mendes et al., 2003), singlet oxygen (Rathakrishnan et al., 1992) and hydroxyl (Tiku et al., 1998) and superoxide anion (Mendes et al., 2003; Tawara et al., 1991) radicals, as well as the reactive nitrogen species NO (Palmer et al., 1993). We have recently observed that ROS, particularly the superoxide anion radical, are required for activation of the nuclear transcription factor-kappaB $(\mathrm{NF}-\kappa \mathrm{B})$ and for the expression of the inducible NO synthase (iNOS) gene induced by IL-1 in bovine articular chondrocytes (Mendes et al., 2001, 2003). Other ROS-mediated IL-1-induced cellular responses in chondrocytes include expression of the c-jun (Lo et al., 1996), c-fos and collagenase (Lo et al., 1998) genes and activation of the c-Jun NH2-terminal kinase (Lo et al., 1996), which phosphorylates c-Jun increasing its transcriptional activity (Kyriakis et al., 1994). Furthermore, chondrocyte-derived ROS have also been shown to mediate cartilage matrix destruction by inducing aggrecan and collagen degradation (Tiku et al., 1999; Tiku et al., 2000).

The protein products of the $c$-fos and $c$-jun genes can heterodimerize to form an Activator Protein-1 (AP-1) transcription factor. AP-1 plays an essential role in mediating some effects of IL-1, namely the expression of the collagenase-1 gene (Lafyatis et al., 1990). Furthermore, AP-1 has recently been implicated in the transcriptional induction of the collagenases- 1 and -3 in response to IL- 1 and other stimuli, both in chondrocytes and synoviocytes (Catterall et al., 2001; Mengshol et al., 2001; Sun et al., 2002). Nevertheless, the role of AP-1 on the expression of other genes whose promoter regions also contain binding sites for this transcription factor is not always so clear. For instance, the promoter region of the iNOS gene from different species contains binding sites for AP-1 (Lowenstein et al., 1993; Chu et al., 1998), but, in different cells, the role of this transcription factor on iNOS expression has been shown to range from induction (MarksKonczalik et al., 1998; Kristof et al., 2001; Giri et al., 2002) to repression (Kleinert et al., 1998; Pance et al., 2002).

Accumulating evidence indicates that AP-1 is sensitive to redox regulation. However, the role of reactive oxygen and nitrogen species on AP-1 activation seems to be highly dependent on the cell type, since the same oxidative stimulus, such as $\mathrm{H}_{2} \mathrm{O}_{2}$ (Devary et al., 1991; Meyer et al., 1993; Flescher et al., 1998; Lakshminarayanan et al., 1998) and NO (Rossi et al., 2000; Zouki et al., 2001), can either induce or repress the activity of this transcription factor when acting in different cells. 
In chondrocytes, we observed previously that NO activates AP-1 DNA-binding, mimicking the effect of IL-1 (Mendes et al., 2002a). Moreover, the requirement of ROS for IL-1 induction of both c-fos and c-jun expression (Lo et al., 1996, 1998), as mentioned above, suggests that ROS may mediate IL-1induced AP-1 activation. Nevertheless, this question has never been addressed directly in chondrocytes and, although $\mathrm{H}_{2} \mathrm{O}_{2}$ has been shown to mimic IL-1-induced c-jun expression in these cells (Lo et al., 1996), its ability to modulate AP-1 activity is unknown. Therefore, the present study aimed at elucidating the role of ROS, particularly that of $\mathrm{H}_{2} \mathrm{O}_{2}$, in mediating IL-1-induced AP-1 activation in articular chondrocytes.

On the other hand, we have also observed that AP-1 activation is not required for IL-1induced iNOS expression in chondrocytes (Mendes et al., 2002b). Therefore, we investigated whether AP-1 is not involved or functions as a negative regulator of the $i N O S$ gene in IL-1-stimulated chondrocytes.

\section{Materials and methods}

\section{Reagents}

Recombinant human IL-1 $\beta$ was purchased from R\&D Systems (Abingdon, UK), $\mathrm{H}_{2} \mathrm{O}_{2}$ from Sigma Chemical Co. (St. Louis, MO, USA), diphenyleneiodonium chloride (DPI) from Calbiochem (San Diego, CA, USA), the anti-iNOS antibody was from Transduction Laboratories (Lexington, KY, USA), the antiactin antibody was from Boehringer Mannheim (Mannheim, Germany). The antibodies against the protein subunits of the Fos and Jun families and the oligonucleotide probes were from Santa Cruz Biotechnology, Inc. (Santa Cruz, CA, USA). The protease inhibitors cocktail, "Complete, Mini", was from Roche Molecular Biochemicals (Mannheim, Germany).
The isotopes were from Amersham Pharmacia Biotech Inc. (Piscataway, NJ, USA). The cDNA probes for iNOS and glyceraldehyde-3phosphate dehydrogenase (GAPDH) were a kind gift from Dr. Tony Cruz (Samuel Lunenfeld Research Institute, Mount Sinai Hospital, Toronto, Canada).

\section{Isolation and cell culture}

Chondrocytes were isolated from bovine articular cartilage, as described previously (Cruz et al., 1990). Primary confluent monolayer cultures were set up by plating $2 \times 10^{6}$ cells $/ \mathrm{ml}$ in Ham's F-12 medium containing 3\% antibiotic/antimycotic solution and 5\% fetal bovine serum and allowed to recover for $24 \mathrm{~h}$ at $37^{\circ} \mathrm{C}$ in a humidified atmosphere supplemented with $5 \% \mathrm{CO}_{2}$. Prior to any treatments, the cells were serum-starved overnight and, thereafter, maintained in culture medium with $1 \%$ antibiotic/antimycotic solution and without serum.

\section{Preparation of cytoplasmic and nuclear extracts}

The cells were lysed in $400 \mu \mathrm{l}$ of buffer 1 (10 $\mathrm{mmol} / \mathrm{L}$ Tris- $\mathrm{HCl}, 10 \mathrm{mmol} / \mathrm{L} \mathrm{NaCl}, 3 \mathrm{mmol} / \mathrm{L}$ $\mathrm{MgCl}_{2}, 0.5 \%$ Nonidet P-40, protease inhibitors cocktail at 1:7 dilution, $\mathrm{pH}$ 7.5) and incubated on ice for $15 \mathrm{~min}$. The lysates were centrifuged at $2300 \mathrm{~g} / 5 \mathrm{~min} / 4^{\circ} \mathrm{C}$ and the supernatants (cytoplasmic extracts) were collected and stored at $-70^{\circ} \mathrm{C}$. The pellets were resuspended in $30 \mu 1$ of buffer $2(20 \mathrm{mmol} / \mathrm{L}$ HEPES, $5 \mathrm{mmol} / \mathrm{L}$ $\mathrm{MgCl}_{2}, 0.2 \mathrm{mmol} / \mathrm{L}$ EDTA, $1 \mathrm{mmol} / \mathrm{L}$ DTT, $300 \mathrm{mmol} / \mathrm{L} \mathrm{NaCl}, 20 \%$ glycerol, protease inhibitors cocktail at 1:7 dilution, $\mathrm{pH}$ 7.5). After a $20 \mathrm{~min}$ incubation on ice, the pellet lysates were centrifuged at $18000 \mathrm{~g} / 20 \mathrm{~min} / 4^{\circ} \mathrm{C}$ and the supernatants (nuclear extracts) were collected and stored at $-70^{\circ} \mathrm{C}$. The protein concentration of the extracts was measured using the bicinchoninic acid/copper (II) sulfate protein assay kit (Sigma). 


\section{Electrophoretic mobility shift assay (EMSA)}

The AP-1 oligonucleotide probe was endlabeled with $\left[\gamma_{-}{ }^{32} \mathrm{P}\right]$ ATP by the T4 polynucleotide kinase and purified through Sephadex G50 spin columns. Nuclear extracts $(10 \mu \mathrm{g}$ protein) were incubated on ice, for $40 \mathrm{~min}$, in $20 \mu \mathrm{l}$ binding reactions containing $20 \mathrm{mmol} / \mathrm{L}$ HEPES, $50 \mathrm{mmol} / \mathrm{L} \mathrm{KCl}, 1 \mathrm{mmol} / \mathrm{L} \mathrm{MgCl}_{2}$, $0.5 \mathrm{mmol} / \mathrm{L}$ DTT, 4\% Ficoll 400, $2 \mu \mathrm{g}$ poly (dIdC), $20 \mu \mathrm{g} \mathrm{BSA}, \mathrm{pH} 7.9$ and $150000 \mathrm{cpm} /$ reaction of $\left[\gamma^{32} \mathrm{P}\right]$-labeled oligonucleotide probe. The DNA-protein complexes were resolved by electrophoresis on 7\% native polyacrylamide gels in $0.5 \times \mathrm{TBE}$ for $3 \mathrm{~h}$ at $150 \mathrm{~V}$, dried and visualized by autoradiography. For supershift analysis, nuclear extracts from IL-1or $\mathrm{H}_{2} \mathrm{O}_{2}$-treated cells were incubated on ice for $2 \mathrm{~h}$ with $2 \mu \mathrm{g} /$ reaction of each antibody, before the addition of the radiolabeled oligonucleotide. Competition assays were performed by simultaneous incubation of the IL-1-treated nuclear extracts with the labeled AP-1 probe and with a 100 -fold excess of the corresponding unlabeled probe or with a 100 -fold excess of unlabeled octamer-1 (Oct-1) probe.

\section{Western blot analysis}

The cytoplasmic extracts ( $25 \mu \mathrm{g}$ protein) were diluted in sodium dodecylsulfate (SDS) sample buffer $(2.5 \%$ SDS, $0.0625 \mathrm{~mol} / \mathrm{L}$ Tris- $\mathrm{HCl}$, $10 \%$ glycerol, 5\% 2-mercaptoethanol, $0.05 \%$ bromophenol blue, $\mathrm{pH}$ 6.8) and boiled for 3 min at $90^{\circ} \mathrm{C}$. Proteins were separated by SDS/ PAGE $[10 \%(\mathrm{w} / \mathrm{v})$ gel] and transferred onto polyvinylidene difluoride (PVDF) membranes by electroblotting. The membranes were blocked with $5 \%$ skim milk in Tris-buffered saline-Tween (TBS-T, $20 \mathrm{mmol} / \mathrm{L}$ Tris- $\mathrm{HCl}$, $150 \mathrm{mmol} / \mathrm{L} \mathrm{NaCl}, 0.1 \%$ Tween-20) and then probed with the anti-iNOS antibody. After extensive washing with TBS-T, the blots were incubated with a horseradish peroxidase-conjugated anti-rabbit antibody (Dako A/S,
Copenhagen, Denmark). The protein-antibody complexes were visualized by chemiluminescence using the ECL western blotting detection reagents from Amersham Pharmacia Biotech Inc. The membranes were subsequently stripped and reprobed with an anti-actin antibody to ensure an equal protein loading.

\section{Northern blot analysis}

Total RNA was extracted using Trizol (Gibco Brl, Life Technologies Inc., Grand Island, NY, USA) and quantitated by spectrophotometry at $260 \mathrm{~nm}$. Denatured RNA samples $(20 \mu \mathrm{g})$ were analyzed by gel electrophoresis in a $1 \%$ denaturing agarose gel, transferred to a nylon membrane and cross-linked by heating at $80^{\circ} \mathrm{C}$ for $30 \mathrm{~min}$. The blots were hybridized with a $\left[{ }^{32} \mathrm{P}\right]$-labeled iNOS c-DNA probe, subsequently stripped and reprobed with a $\left[{ }^{32} \mathrm{P}\right]-$ labeled glyceraldehyde-3-phosphate dehydrogenase (GAPDH) c-DNA as an internal standard to insure a roughly equal loading. The cDNA probes were labeled with $\left[\alpha-{ }^{32} \mathrm{P}\right] \mathrm{dCTP}$ by the klenow fragment using the Random Primed DNA Labeling kit from Boehringer Mannheim GmbH.

\section{Results}

Inhibition of IL-1-induced ROS production prevents AP-1 activation

To detect AP-1 activation, we evaluated, by EMSA analysis, the ability of the proteins present in the nuclear extracts from cells treated with IL-1, in the presence or absence of DPI, to form complexes with a $\left[\gamma-{ }^{32} \mathrm{P}\right]$-labeled oligonucleotide probe containing the consensus binding sequence for that transcription factor.

The results in Figure 1A show that nuclear extracts from IL-1-treated cells elicit the formation of an intense slower migrating band 


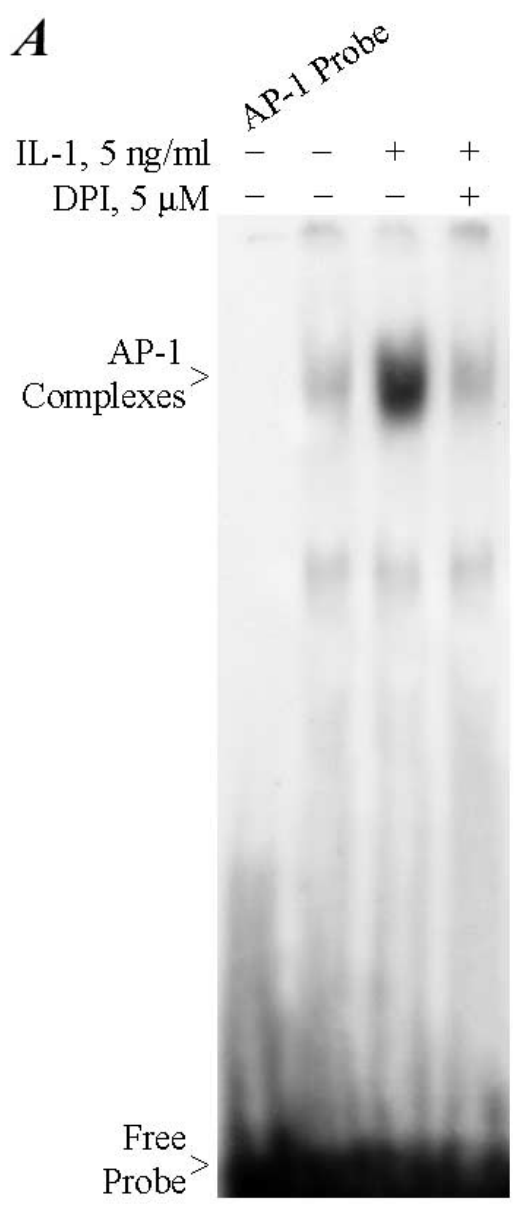

\section{$\boldsymbol{B}$}

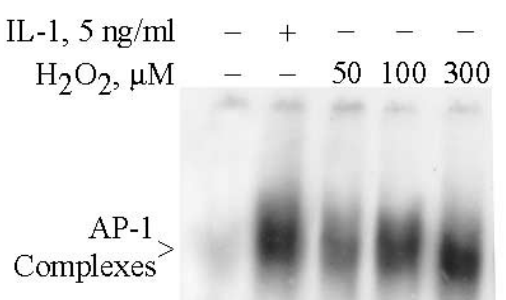

Free

Probe $>$

Figure 1. Reactive oxygen species, namely $\mathrm{H}_{2} \mathrm{O}_{2}$, mediate IL-1-induced AP-1 activation. A: Inhibition of ROS production prevents IL1-induced AP-1 activation. Chondrocyte cultures were pretreated with DPI $(5 \mu \mathrm{mol} / \mathrm{L})$ for $2 \mathrm{~h}$, before the addition of IL-1 $(5 \mathrm{ng} / \mathrm{ml})$ for $3 \mathrm{~h}$. B: Dose-dependent activation of AP-1 by $\mathrm{H}_{2} \mathrm{O}_{2}$. Chondrocyte cultures were treated with the indicated concentrations of $\mathrm{H}_{2} \mathrm{O}_{2}$ for $3 \mathrm{~h}$. The nuclear extracts, prepared as described under "Materials and methods", were used to detect AP-1 binding to a specific oligonucleotide probe by EMSA. The autoradiography shown in panel $\mathrm{A}$ is representative of three distinct experiments and that shown in panel B is representative of four distinct experiments.

corresponding to the binding of AP-1 proteins to the $\left[\gamma_{-}{ }^{32} \mathrm{P}\right]$-labeled oligonucleotide probe. Competition assays, using either a 100 -fold excess of unlabeled AP-1 probe or a 100-fold excess of unlabeled Oct-1 probe (Figure 3A), indicated that the retarded band detected on the autoradiography represents the formation of specific complexes between AP-1 proteins and the AP-1-specific oligonucleotide probe.

Diphenyleneiodonium chloride (DPI), which completely inhibits IL-1-induced ROS production (Lo et al., 1998; Mendes et al., 2001), was effective in preventing IL-1-induced AP-1 activation, as indicated by the absence of the corresponding band in the electrophoretic mobility shift assay shown in Figure 1A. This inhibition cannot be accounted for by toxic effects of DPI, since we observed previously that, in concentrations up to $10 \mu \mathrm{mol} / \mathrm{L}$, this compound does not affect the viability of 
articular chondrocytes, cultured under conditions identical to those used in this study (Mendes et al., 2001).

\section{$\mathrm{H}_{2} \mathrm{O}_{2}$ is sufficient to induce AP-1 activation}

The results in Figure 1B show that $\mathrm{H}_{2} \mathrm{O}_{2}$ induced the formation of complexes migrating more slowly than the unbound, free oligonucleotide probe. As shown for IL-1, competition assays indicated that the retarded band detected on the autoradiography obtained with nuclear extracts from $\mathrm{H}_{2} \mathrm{O}_{2}$-treated cells represents the formation of specific complexes between AP-1 proteins and the AP-1-specific oligonucleotide probe (Figure 3B). Furthermore, the intensity of the bands shown in Figure 1B increased with increasing concentrations of $\mathrm{H}_{2} \mathrm{O}_{2}$, thus showing a dose-dependent activation of AP-1 by $\mathrm{H}_{2} \mathrm{O}_{2}$. Taken together, these results and those in Figure 1A show that $\mathrm{H}_{2} \mathrm{O}_{2}$ is sufficient to induce AP-1 activation and that ROS, namely $\mathrm{H}_{2} \mathrm{O}_{2}$, mediate AP-1 activation in response to IL-1.

To further evaluate the relevance of AP-1 activation by $\mathrm{H}_{2} \mathrm{O}_{2}$, we studied the pattern of AP-1 activation as a function of the incubation time with IL-1 and with $\mathrm{H}_{2} \mathrm{O}_{2}$. The results in Figure 2 show that after $30 \mathrm{~min}$ incubation with $\mathrm{H}_{2} \mathrm{O}_{2}$, the AP-1 complexes were already detectable, reaching maximum intensity at $3 \mathrm{~h}$ and decreasing thereafter. In contrast, $1 \mathrm{~h}$ incubation with IL-1 was required for the AP1 complexes to be detectable, increasing thereafter in a manner identical to what happened with $\mathrm{H}_{2} \mathrm{O}_{2}$ treatment. These results further suggest that $\mathrm{H}_{2} \mathrm{O}_{2}$ mediates IL-1-induced AP1 activation. Indeed, if $\mathrm{H}_{2} \mathrm{O}_{2}$ has to be produced, in response to IL-1, for AP-1 activation to occur, it is not surprising that direct addition of $\mathrm{H}_{2} \mathrm{O}_{2}$ to the cell cultures activated AP-1 more rapidly than treatment with IL-1.

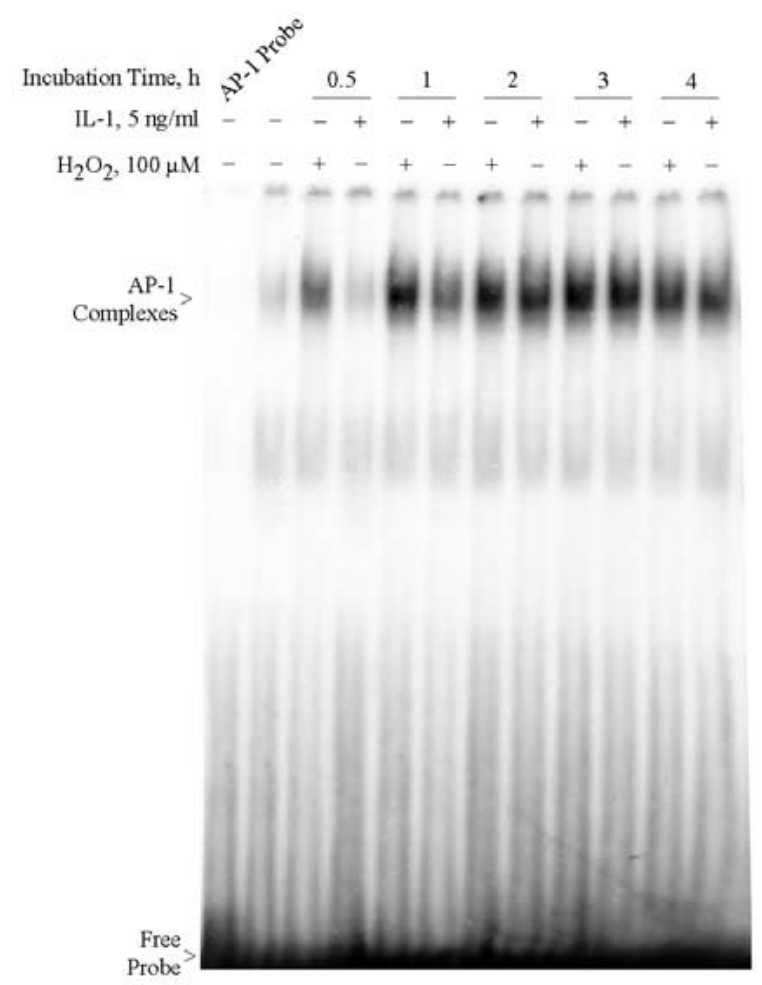

Figure 2. Time-dependent activation of AP-1 by IL-1 and $\mathrm{H}_{2} \mathrm{O}_{2}$. Chondrocyte cultures were treated with IL-1 $(5 \mathrm{ng} / \mathrm{ml})$ or with $\mathrm{H}_{2} \mathrm{O}_{2}(100 \mu \mathrm{mol} / \mathrm{L})$ for the indicated time periods $(0.5-4 \mathrm{~h})$. The nuclear extracts, prepared as described under "Materials and methods", were used to detect AP-1 binding to a specific oligonucleotide probe by EMSA. The autoradiography shown is representative of three distinct experiments.

The AP-1 complexes, induced by IL-1 and by $\mathrm{H}_{2} \mathrm{O}_{2}$, contain c-Fos/c-Jun and c-Fos/JunD heterodimers

Supershift analysis with antibodies against the protein subunits of the Fos and Jun families was used to characterize and compare the protein composition of the AP-1 complexes induced by IL-1 and by $\mathrm{H}_{2} \mathrm{O}_{2}$. The results obtained show that incubation of the nuclear extracts from either IL-1-treated cells (Figure $3 \mathrm{~A}$ ) or $\mathrm{H}_{2} \mathrm{O}_{2}$-treated cells (Figure $3 \mathrm{~B}$ ) with antibodies against the proteins c-Fos and JunD, prior to the addition of the $\left[\gamma-{ }^{32} \mathrm{P}\right]-$ 

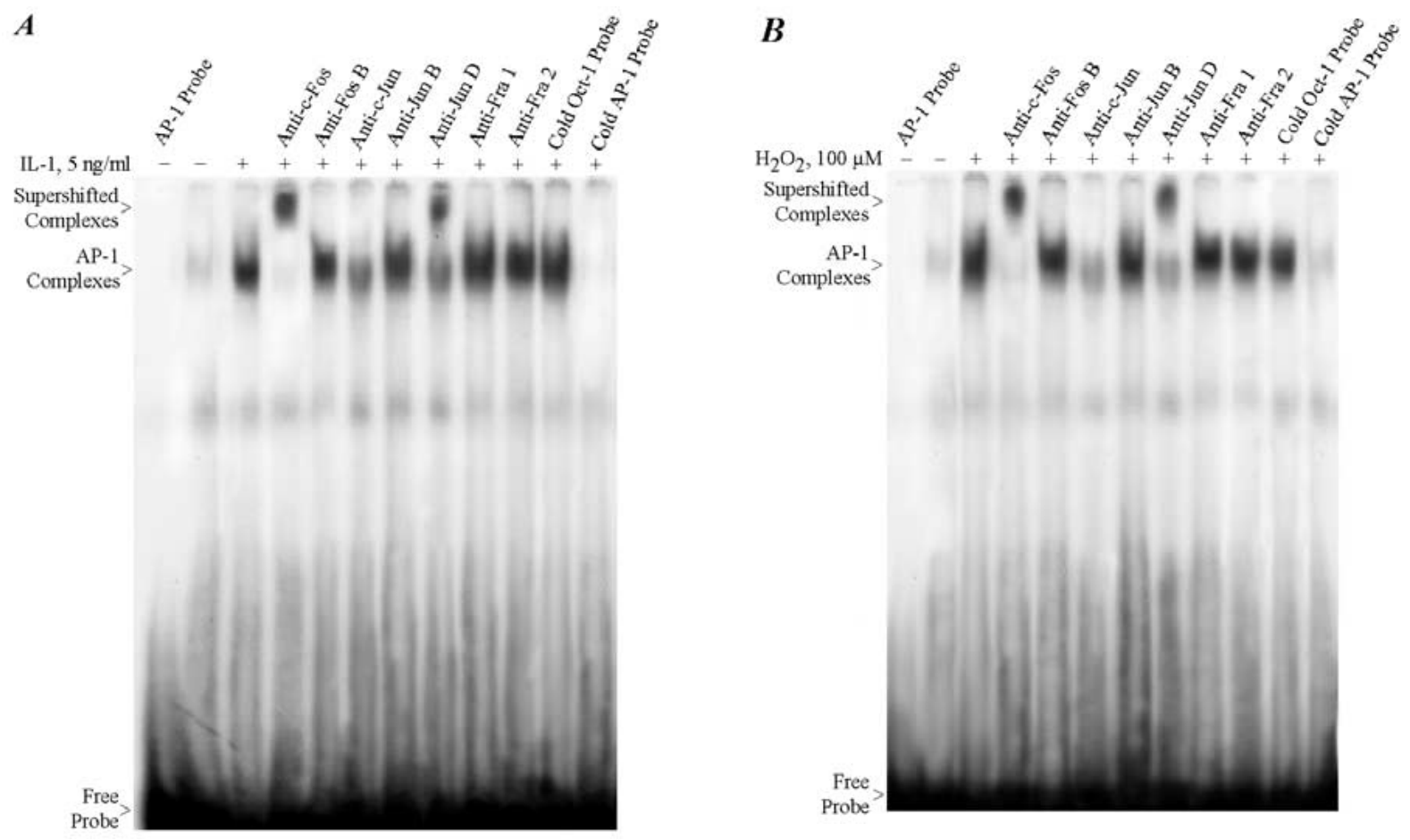

Figure 3. Characterization of the AP-1 complexes induced by IL-1 and by $\mathrm{H}_{2} \mathrm{O}_{2}$. A: characterization of the AP-1 complexes induced by IL-1; B: characterization of the AP-1 complexes induced by $\mathrm{H}_{2} \mathrm{O}_{2}$. Chondrocyte cultures were treated with IL-1 (5 ng/ml) or with $\mathrm{H}_{2} \mathrm{O}_{2}(100 \mu \mathrm{mol} / \mathrm{L})$ for $3 \mathrm{~h}$. Competition and supershift assays were performed as described under "Materials and methods". The autoradiographies shown are representative of three distinct experiments.

labeled AP-1 probe, elicited the formation of slower migrating complexes that appear in the autoradiography closer to the origin of the gel. This indicates that the supershifted bands contain the proteins c-Fos and JunD. In identical assays using an antibody against the c-Jun protein, no supershifted bands were detected, but the intensity of the AP-1-oligonucleotide probe complexes was greatly reduced (Figures $3 \mathrm{~A}$ and $3 \mathrm{~B}$ ). This indicates that binding of the antibody to AP-1 dimers containing the protein c-Jun prevented the binding of those dimers to the oligonucleotide probe. Antibodies against the other members of the Fos and Jun families, namely anti-FosB, anti-JunB, anti-Fra1 and anti-Fra2, had no appreciable effect on the intensity or on the electrophoretic mobility of the AP-1oligonucleotide probe complexes (Figures 3A and 3B). Therefore, it seems that the AP-1 dimers, induced by either IL-1 or $\mathrm{H}_{2} \mathrm{O}_{2}$ in articular chondrocytes, are mainly composed of the proteins c-Fos, c-Jun and JunD. The Jun proteins are probably arranged in heterodimers with c-Fos, since the Fos proteins cannot form homodimers (Angel and Karin, 1991) and the anti-c-Fos antibody completely supershifted the AP-1 complexes, whereas the anti-c-Jun and the anti-JunD antibodies only partially abrogated or supershifted the AP-1 complexes. 
AP-1 activation does not repress $I L-1$-induced iNOS expression

To investigate the role of AP-1 on the transcriptional regulation of iNOS expression in articular chondrocytes, we took advantage of the observed ability of $\mathrm{H}_{2} \mathrm{O}_{2}$ to induce AP-1 activity (Figures 1B, 2 and 3) without inducing or even being required for iNOS expression (Mendes et al., 2003). Thus, AP-1 activity was induced by treating the chondrocyte cultures with $\mathrm{H}_{2} \mathrm{O}_{2}(50-300 \mu \mathrm{mol} / \mathrm{L})$ for $2 \mathrm{~h}$ before the addition of IL-1. The cells were then incubated with IL-1 $(5 \mathrm{ng} / \mathrm{ml})$ for 5 or $16 \mathrm{~h}$ and the iNOS mRNA and protein levels, respectively, were determined. The results in Figure 4 show that pre-treatment with $\mathrm{H}_{2} \mathrm{O}_{2}$ had no effect on the iNOS mRNA and protein levels induced by IL-1. Therefore, these results show that AP-1 activation does not repress IL-1-induced iNOS expression in articular chondrocytes.

\section{Discussion}

In agreement with other reports (Tawara et al., 1991; Rathakrishnan et al., 1992; Tiku et al., 1998), our previous studies showed that chondrocytes produce ROS in response to IL-1 (Mendes et al., 2001, 2003) and that $\mathrm{H}_{2} \mathrm{O}_{2}$ constitutes a large fraction of the total ROS produced (Mendes et al., 2003). We have also observed that DPI, a selective inhibitor of flavonoid-containing enzymes, such as NADPH oxidase, NADH oxidase, quinone oxidoreductase and cytochrome P450 reductase, prevents IL-1-induced ROS production in a concentration-dependent manner (Mendes et al., 2001). In the present study, we also found that DPI effectively prevented IL-1induced AP-1 activation (Figure 1A), thus indicating that ROS are required for and mediate this response to IL-1.

$\mathrm{H}_{2} \mathrm{O}_{2}$ has been extensively used as an oxidative stimulus to study the role of ROS on many cellular processes, namely on AP-1 activation, in a variety of cells. The ability of $\mathrm{H}_{2} \mathrm{O}_{2}$ to activate AP-1 in different cells is well documented (Devary et al., 1991; Lakshminarayanan et al., 1998; Zhou et al., 2001). However, the opposite effect, that is, inhibition of AP-1 activation by pro-oxidant stimuli or induction by antioxidants, has also been reported (Meyer et al., 1993; Wesselborg et al., 1997; Flescher et al., 1998). It has been suggested that these discrepancies may reflect cell type-specific mechanisms of AP-1 regulation (Karin et al., 1997; Shaulian and Karin, 2002). The results presented here show that, in articular chondrocytes, $\mathrm{H}_{2} \mathrm{O}_{2}$ activates AP- 1 in a dose-dependent manner (Figure 1B), mimicking the response induced by IL-1 (Figure 1A). The protein composition (Figure 3) and the temporal pattern (Figure 2) of AP-1 activation in response to $\mathrm{H}_{2} \mathrm{O}_{2}$ and IL-1 were identical. Nevertheless, AP-1 dimers, capable of binding to an AP-1-specific oligonucleotide probe, were induced more rapidly by $\mathrm{H}_{2} \mathrm{O}_{2}$ than by IL-1 (Figure 2). This indicates that $\mathrm{H}_{2} \mathrm{O}_{2}$ has to be produced in response to IL-1, before AP1 activation can occur. Taken together, the results presented show that $\mathrm{H}_{2} \mathrm{O}_{2}$ is a major ROS involved in mediating IL-1-induced AP-1 activation in articular chondrocytes.

The promoter region of the iNOS gene from different species contains AP-1-binding sites (Lowenstein et al., 1993; Chu et al., 1998), but the role of this transcription factor in the expression of iNOS seems to vary considerably in different cells, even within the same species. For instance, in human lung epithelial cells (Marks-Konczalik et al., 1998; Kristof et al., 2001) and in C6 glioma cells (Giri et al., 2002), AP-1 has been shown to mediate induction of iNOS expression, whereas in human colon tumor epithelial cell lines it was shown to have a repressor effect (Kleinert et al., 1998; Pance et al., 2002). We have previously observed that AP-1 is not required for IL-1-induced iNOS expression in articular chondrocytes, indicat- 


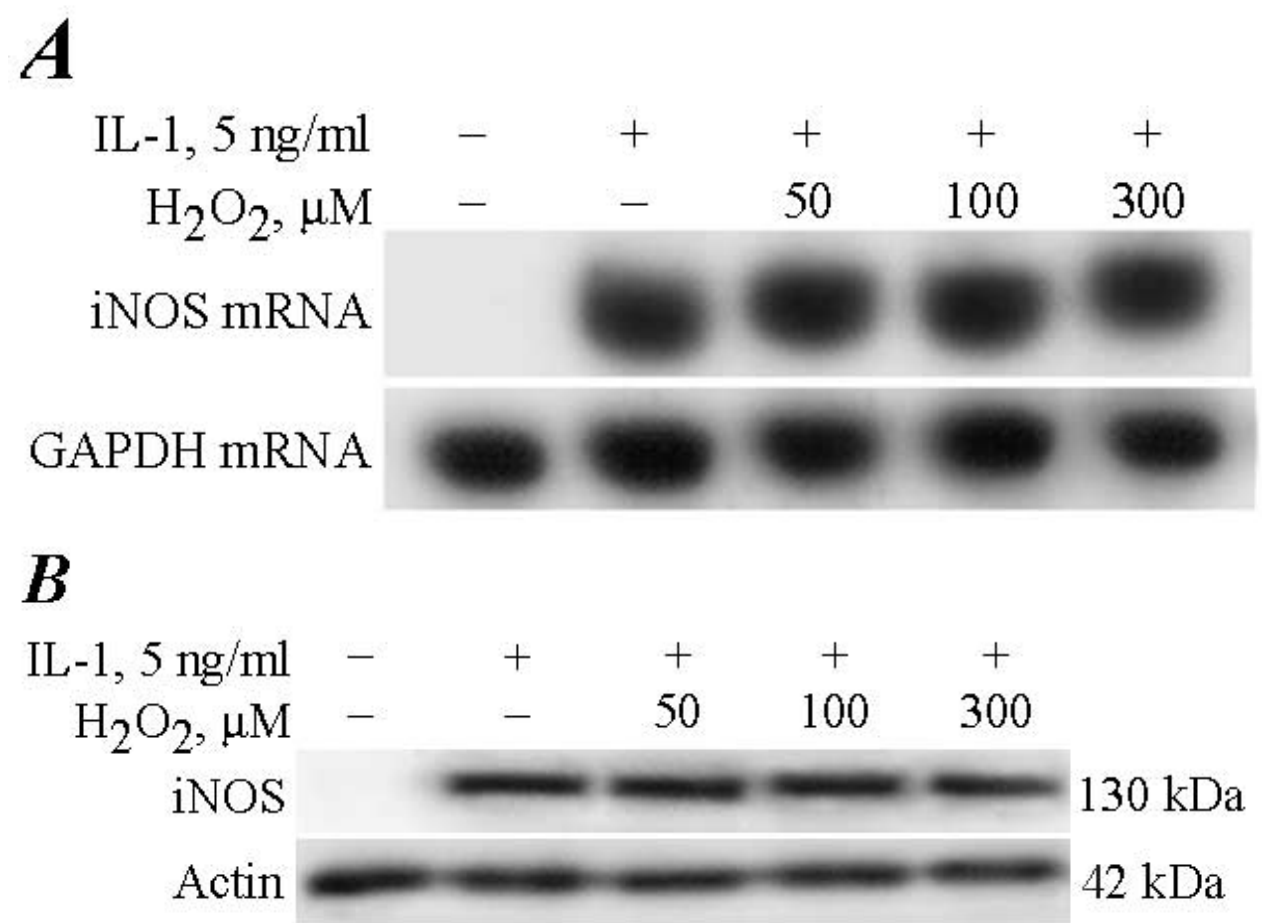

Figure 4. $\mathrm{H}_{2} \mathrm{O}_{2}$ pre-treatment does not affect IL-1-induced iNOS expression. A: effect of $\mathrm{H}_{2} \mathrm{O}_{2}$ pre-treatment on IL-1-induced iNOS mRNA levels; B: effect of $\mathrm{H}_{2} \mathrm{O}_{2}$ pre-treatment on IL-1-induced iNOS protein levels. Chondrocyte cultures were treated with the indicated concentrations of $\mathrm{H}_{2} \mathrm{O}_{2}$ for $2 \mathrm{~h}$ before the addition of IL-1 $(5 \mathrm{ng} / \mathrm{ml})$ and then further incubated for $5 \mathrm{~h}(\mathrm{~A})$ or $16 \mathrm{~h}$ (B). The iNOS mRNA and protein levels were determined by Northern and Western blot analysis, respectively, as described under "Materials and methods". The autoradiographies shown are representative of three distinct experiments.

ing that this transcription factor is not an inducer of the iNOS promoter (Mendes et al., 2002b). However, this finding does not exclude the possibility that AP-1 can behave as a negative regulator or repressor of the iNOS promoter in articular chondrocytes.

To elucidate this question, we took advantage of the ability of $\mathrm{H}_{2} \mathrm{O}_{2}$ to activate this transcription factor (Figures 1B, 2 and 3B), without interfering with iNOS expression (Mendes et al., 2003). In fact, we found recently that, although ROS, particularly the superoxide anion, are required for IL-1induced iNOS expression mediated by NF- $\mathrm{BB}$ (Mendes et al., 2001, 2003), $\mathrm{H}_{2} \mathrm{O}_{2}$ does neither induce by itself nor does it mediate, enhance or inhibit IL-1-induced NF- $\kappa$ B activation and the subsequent expression of iNOS in articular chondrocytes (Mendes et al., 2003). Hence, we used $\mathrm{H}_{2} \mathrm{O}_{2}$ to specifically activate AP- 1 , before stimulation of the cells with IL-1, so that the role of this transcription factor on iNOS expression could be evaluated. The results presented here show that pre-activation of AP-1, by treatment of the cells with $\mathrm{H}_{2} \mathrm{O}_{2}$, did not inhibit IL-1-induced iNOS expression (Figure 4). Therefore, we can conclude that AP-1 is not a repressor of the iNOS promoter and, therefore, does not participate in the transcriptional regulation of the $i N O S$ gene in bovine articular chondrocytes.

Recent reviews, concerning the activation modes and functions of AP-1, suggest that different AP-1 dimers may have distinct roles 
in the regulation of gene transcription (Karin et al., 1997; Shaulian and Karin, 2002). The heterodimer c-Fos/c-Jun has the highest affinity for the AP-1 site and the highest transactivation activity (Karin et al., 1997; Shaulian and Karin, 2002). However, recent studies indicate that other AP-1 dimers, distinct from the classical c-Fos/c-Jun, can participate on the regulation of gene expression. Indeed, various AP-1 complexes containing either Fra2/JunD (Marks-Konczalik et al., 1998; Kristof et al., 2001), JunB, c-Jun and JunD (Cho et al., 2002) or Fral (Giri et al., 2002), were reported to be involved in inducing the transcription of the iNOS gene in different cells. Hence, at least, some of the discrepancies concerning the role of AP-1 on the transcriptional regulation of the $i N O S$ gene may result from the induction of different AP-1 dimers in response to a given stimulus in different cells, or in response to distinct stimuli in the same cell-type. Nevertheless, the presence of active AP-1 dimers in the cultured chondrocytes, at the time of IL-1 treatment, did not alter iNOS expression relatively to cells treated with IL-1 alone (Figure 4). Therefore, these results exclude a role for AP-1, regardless of its composition, on the transcriptional regulation of the iNOS gene in articular chondrocytes.

Although not required for the expression of iNOS, the AP-1 complexes induced by IL-1 and $\mathrm{H}_{2} \mathrm{O}_{2}$ in chondrocytes may be relevant for the induction of other genes whose protein products also play significant roles in the pathophysiology of arthritic diseases. One of those is interleukin-8 (IL-8), a cytokine that has been implicated in a variety of inflammatory diseases, including arthritis (Luster, 1998). Various stimuli, namely IL-1, have been shown to induce IL-8 expression in articular chondrocytes (Recklies and Golds, 1992; Pulsatelli et al., 1999). On the other hand, the c-Fos/JunD complex has been reported to mediate induction of the IL-8 gene in response to either tumor necrosis factor- $\alpha$ or $\mathrm{H}_{2} \mathrm{O}_{2}$ in A549 epithelial cells (Lakshminarayanan et al., 1998). Interestingly, we found that, besides cFos and c-Jun, the AP-1 complexes, induced by either IL-1 or $\mathrm{H}_{2} \mathrm{O}_{2}$, also contained JunD, probably arranged in heterodimers with c-Fos (Figure 3). Therefore, it will be interesting to study the role of this particular AP-1 transcription factor on IL-1-induced IL-8 expression in articular chondrocytes. Moreover, the c-Fos/ JunD complex has also been shown to bind to AP-1 sites in the promoter region of the collagenase- 1 gene and to be essential for its transcriptional induction (White and Brinckerhoff, 1995). Thus, our results suggest that this particular AP-1 transcription factor may also play an important role on $\mathrm{H}_{2} \mathrm{O}_{2}$-mediated IL1-induced collagenase- 1 expression in articular chondrocytes.

\section{Conclusion}

The results presented here indicate that $\mathrm{H}_{2} \mathrm{O}_{2}$ is a major ROS mediating IL-1-induced AP-1 activation, in articular chondrocytes, by inducing the formation of c-Fos/c-Jun and c-Fos/ JunD dimers. Furthermore, this study also shows that inhibition of ROS production, namely suppression of $\mathrm{H}_{2} \mathrm{O}_{2}$ synthesis, is an effective strategy to prevent IL-1-induced AP-1 activation in articular chondrocytes. On the other hand, this study shows that, in articular chondrocytes, AP-1 is not a repressor of the iNOS gene promoter. Nevertheless, given the importance of IL-1-induced gene expression in arthritic diseases, the roles of the distinct AP-1 complexes in mediating the various IL-1induced responses, as well as the mechanisms that regulate the activity and specificity of those complexes, deserve to be further investigated. 


\section{Acknowledgments}

This work was supported by the Portuguese Foundation for Science and Technology (FCT), SAPIENS, Ref. 43639/99.

\section{References}

Angel P, Karin M. The role of Jun, Fos and the AP-1 complex in cell-proliferation and transformation. Biochem Biophys Acta. 1991;1072:129-57.

Catterall JB, Carrère S, Koshy PJ, et al. Synergistic induction of matrix metalloproteinase 1 by interleukin- $1 \alpha$ and oncostatin $\mathrm{M}$ in human chondrocytes involves signal transducer and activator of transcription and activator protein 1 transcription factors via a novel mechanism. Arthritis Rheum. 2001;44:2296-310.

Cho MK, Suh SH, Kim SG. JunB/AP-1 and NF-kB-mediated induction of nitric oxide synthase by bovine type I collagen in serum-stimulated murine macrophages. Nitric Oxide. 2002;6:319-32.

Chu SC, Marks-Konczalik J, Wu H-P, Banks TC, Moss J. Analysis of the cytokine-stimulated human inducible nitric oxide synthase (iNOS) gene: characterization of differences between human and mouse iNOS promoters. Biochem Biophys Res Commun. 1998;248:871-8.

Cruz TF, Mills G, Pritzker KPH, Kandel RA. Inverse correlation between tyrosine phosphorylation and collagenase poduction in chondrocytes. Biochem J. 1990;269:717-21.

Devary Y, Gottlieb RA, Lau LF, Karin M. Rapid and preferential activation of the c-jun gene during the mammalian UV response. Mol Cell Biol. 1991;11:2804-11.

Eberhardt W, Beck KF, Pfeilschifter J. Cytokine-induced expression of tPA is differentially modulated by NO and ROS in rat mesangial cells. Kidney Int. 2002;61:20-30.

Flescher E, Tripoli H, Salnikow K, Burns FJ. Oxidative stress suppresses transcription factor activities in stimulated lymphocytes. Clin Exp Immunol. 1998;112:242-7.

Giri S, Jatana M, Rattan R, Won JS, Singh I, Singh AK. Galactosylsphingosine (psychosine)-induced expression of cytokine-mediated inducible nitric oxide synthases via AP-1 and C/EBP: implications for Krabbe disease. FASEB J. 2002;16:661-72.

Goldring MB, Fukuo K, Birkhead JR, Dudek E, Sandell LF. Transcriptional suppression by interleukin-1 and interferongamma of type II collagen gene expression in human chondrocytes. J Cell Biochem. 1994;54:85-99.

Karin M, Liu Z-G, Zandi E. AP-1 function and regulation. Curr Opin Cell Biol. 1997;9:240-6.

Kleinert H, Wallerath T, Fritz G, et al. Cytokine induction of NO synthase II in human DLD-1 cells: roles of the JAKSTAT, AP-1 and NF-kB-signaling pathways. Br J Pharmacol. 1998;125:193-201.

Knott I, Dieu M, Burton M, Houbion A, Remacle J, Raes M. Induction of cyclooxygenase by interleukin 1: comparative study between human synovial cells and chondrocytes. J Rheumatol. 1994;21:462-6.

Kristof AS, Marks-Konczalik J, Moss J. Mitogen-activated protein kinases mediate activator protein-1-dependent human inducible nitric oxide synthase promoter activation. J Biol Chem. 2001;276:8445-52.

Kuo PC, Abe KY, Schroeder RA. Oxidative stress increases hepatocyte iNOS gene transcription and promoter activity. Biochem Biophys Res Commun. 1997;234:289-92.

Kyriakis JM, Banerjee P, Nikolakaki E, et al. The stressactivated protein kinase subfamily of $c$-jun kinases. Nature. 1994;369:156-60.

Lafyatis R, Kim S-J, Angel P, et al. Interleukin-1 stimulates and all-trans-retinoic acid inhibits collagenase gene expression through its $5^{\prime}$ activator protein-1-binding site. Mol Endocrinol. 1990;4:973-80.

Lakshminarayanan V, Drab-Weiss EA, Roebuck KA. $\mathrm{H}_{2} \mathrm{O}_{2}$ and tumor necrosis factor- $\alpha$ induce differential binding of the redox-responsive transcription factors AP- 1 and NF- $\kappa \mathrm{B}$ to the interleukin-8 promoter in endothelial and epithelial cells. J Biol Chem. 1998;273:32670-8.

Lo YYC, Wong JMS, Cruz TF. Reactive oxygen species mediate cytokine activation of c-Jun NH2-terminal kinases. J Biol Chem. 1996;271:15703-7.

Lo YYC, Conquer JA, Grinstein S, Cruz TF. Interleukin-1 $\beta$ induction of c-fos and collagenase expression in articular chondrocytes: involvement of reactive oxygen species. J Cell Biochem. 1998;69:19-29.

Lowenstein CJ, Alley EW, Raval P, et al. Macrophage nitric oxide synthase gene: two upstream regions mediate induction by interferon-gamma and lipopolysaccharide. Proc Natl Acad Sci USA. 1993;90:9730-4.

Luster AD. Chemokines-chemotactic cytokines that mediate inflammation. N Engl J Med. 1998;338:436-45.

Marks-Konczalik J, Chu SC, Moss J. Cytokine-mediated transcriptional induction of the human inducible nitric oxide synthase gene requires both activator protein 1 and nuclear factor kappaB-binding sites. J Biol Chem. 1998;273:22201-

Mendes AF, Carvalho AP, Caramona MM, Lopes MC. Diphenyleneiodonium inhibits NF- $\mathrm{kB}$ activation and iNOS expression induced by IL-1 $\beta$ : involvement of reactive oxygen species. Med Inflamm. 2001;10:209-15.

Mendes AF, Carvalho AP, Caramona MM, Lopes MC. Role of nitric oxide on the activation of NF- $\mathrm{KB}, \mathrm{AP}-1$ and NOS II expression in articular chondrocytes. Inflamm Res. 2002a; 51:369-75.

Mendes AF, Caramona MM, Carvalho AP, Lopes MC. Role of mitogen-activated protein kinases and tyrosine kinases on IL-1-induced NF- $\kappa \mathrm{B}$ activation and iNOS expression in bovine articular chondrocytes. Nitric Oxide. 2002b;6:35-44.

Mendes AF, Caramona MM, Carvalho AP, Lopes MC. Differential roles of hydrogen peroxide and superoxide in mediating IL-1-induced NF- $\kappa \mathrm{B}$ activation and iNOS expression in bovine articular chondrocytes. J Cell Biochem. 2003;88: 783-93.

Mengshol JA, Vincenti MP, Brinckerhoff CE. IL-1 induces collagenase-3 (MMP-13) promoter activity in stably transfected chondrocytic cells: requirement for Runx-2 and 
activation by p38 MAPK and JNK pathways. Nucleic Acids Res. 2001;29:4361-72.

Meyer M, Schreck R, Baeuerle PA. $\mathrm{H}_{2} \mathrm{O}_{2}$ and antioxidants have opposite effects on activation of NF- $\mathrm{\kappa B}$ and AP-1 in intact cells: AP-1 as secondary antioxidant-responsive factor. EMBO J. 1993;12:2005-15.

Palmer RMJ, Hickery MS, Charles IG, Moncada S, Bayliss MT. Induction of nitric oxide synthase in human chondrocytes. Biochem Biophys Res Commun. 1993;193:398-405.

Pance A, Chantome A, Reveneau S, Bentrari F, Jeannin JF. A repressor in the human inducible nitric oxide synthase promoter modulates transcriptional activation. FASEB J. 2002;16:631-3.

Pelletier JP, DiBattista JA, Roughley P, McCollum R, MartelPelletier J. Cytokines and inflammation in cartilage degradation. Rheum Dis Clin N Am. 1993;19:545-68.

Pulsatelli L, Dolzani P, Piacentini A, et al. Chemokine production by human chondrocytes. J Rheumatol. 1999;26:19922001.

Rathakrishnan C, Tiku K, Raghaven A, Tiku ML. Release of oxygen radicals by articular chondrocytes: a study of luminol-dependent chemiluminescence and hydrogen peroxide secretion. J Bone Min Res. 1992;7:1139-48.

Recklies AD, Golds EE. Induction of synthesis and release of interleukin-8 from human articular chondrocytes and cartilage explants. Arthritis Rheum. 1992;35:1510-9.

Rossi A, Catani MV, Candi E, Bernassola F, Puddu P, Melino G. Nitric oxide inhibits cornified envelope formation in human keratinocytes by inactivating transglutaminases and activating protein 1. J Invest Dermatol. 2000;115:731-9.

Shaulian E, Karin M. AP-1 as a regulator of cell life and death. Nature Cell Biol. 2002;4:E131-6.

Sun Y, Wenger L, Brinckerhoff CE, Misra RR, Cheung HS Basic calcium phosphate crystals induce matrix metalloproteinase-1 through the Ras/mitogen-activated protein $\mathrm{ki}$ nase/c-Fos/AP-1/metalloproteinase 1 pathway. Involvement of transcription factor binding sites AP-1 and PEA-3. J Biol Chem. 2002;277:1544-52.

Taskiran D, Stefanovic-Racic M, Georgescu H, Evans C. Nitric oxide mediates suppression of cartilage proteoglycan synthesis by interleukin-1. Biochem Biophys Res Commun. 1994; 200:142-8.
Tawara T, Shingu M, Nobunaga M, Naono T. Effects of recombinant human IL-1 $\beta$ on production of prostaglandin $\mathrm{E} 2$, leukotriene B4, NAG and superoxide by human synovial cells and chondrocytes. Inflammation. 1991;15:145-57.

Tiku ML, Yan, YP, Chen KY. Hydroxyl radical formation in chondrocytes and cartilage as detected by electron paramagnetic resonance spectroscopy using spin trapping reagents. Free Radic Res. 1998;29:177-87.

Tiku ML, Gupta S, Deshmukh DR. Aggrecan degradation in chondrocytes is mediated by reactive oxygen species and protected by antioxidants. Free Radic Res. 1999;30:395405.

Tiku ML, Shah R, Allison GT. Evidence linking chondrocyte lipid peroxidation to cartilage protein degradation. Possible role in cartilage aging and the pathogenesis of osteoarthritis. J Biol Chem. 2000;275:20069-76.

Wesselborg S, Bauer MKA, Vogt M, Schmitz ML, SchulzeOsthoff K. Activation of transcription factor NF- $\mathrm{KB}$ and p38 mitogen-activated protein kinase is mediated by distinct and separate stress effector pathways. J Biol Chem. 1997; 272:12422-9.

Weyand CM. New insights into the pathogenesis of rheumatoid arthritis. Rheumatology. 2000;39(Suppl. 1):3-8.

White LA, Brinckerhoff CE. Two activator protein-1 elements in the matrix metalloproteinase-1 promoter have different effects on transcription and bind Jun D, c-Fos, and Fra-2. Matrix Biol. 1995;14:715-25.

Zhou LZ, Johnson AP, Rando TA. NF-kB and AP-1 mediate transcriptional responses to oxidative stress in skeletal muscle cells. Free Radic Biol Med. 2001;31:1405-16.

Zouki C, József L, Oullet S, Paquette Y, Filep JG. Peroxynitrite mediates cytokine-induced IL-8 gene expression and production by human leukocytes. J Leukoc Biol. 2001;69:81524.

Address for correspondence: Alexandrina Ferreira Mendes, Centre for Neurosciences and Cell Biology, Department of Zoology, University of Coimbra, 3004-517 Coimbra, Portugal E-mail: afmendes@ff.uc.pt 